\title{
Pengaturan Dosis Asap Cair Berbahan Baku Tempurung Kelapa Sebagai Bahan Penggumpal Lateks
}

\section{(Liquid Smoke Dosage Adjustment from Coconut Shell as Latex Coagulant)}

\author{
Andrevil Sarbaini $^{1{ }^{*}}$, Rachmad Edison ${ }^{2)}$, Febrina Delvitasari ${ }^{2)}$ \\ 1) Program Studi Produksi dan Manajemen Industri Perkebunan Politeknik Negeri Lampung dan \\ 2) Jurusan Budidaya Tanaman Perkebunan Politeknik Negeri Lampung, Jl. Soekarno-Hatta No. 10 \\ Rajabasa, Bandar Lampung, 35144, Telp.: (0721) 703995, Fax.: (0721) 787309 \\ E-mail: andrevilsarbaini09@gmail.com
}

\begin{abstract}
In the processing of solid rubber, such as the manufacture of crumb rubber and rubber smoke sheet, one of the most important stages is the coagulation process using coagulant. The coagulation process is instrumental in determining for quality the rubber produced. Low quality of bokar is caused by farmers using coagulant which are not recommended. Because of that, it's necessary to found the alternative coagulant that does not damage the quality and the price is relatively cheap. The purpose of this research is gets the best dosage of coconut shell liquid smoke for latex coagulation and to evaluate quality crepe rubber coagulum using coconut shell liquid smoke. The quality observed is dirt content, ash content, volatile matter, PRI, Mooney viscosity, and color index was implemented at PTPN VII, Way Berulu, Pesawaran District. The doses used were 0,1\%, 1,5\%, 2\%, 2,5\%, and 3\%. The result showed that the most effective dose used in this research was $1 \%$ with quality approaching formic acid treatment.
\end{abstract}

Keywords: coconut shell, formic acid, latex coagulant, liquid smoke

DOI: http://dx.doi.org/10.25181/jaip.v6i2.791

Diterima: 9 April 2018 / Disetujui: 16 Agustus 2018 / Diterbitkan: 14 Oktober 2018

\section{PENDAHULUAN}

Karet sebagai komoditi ekspor dan bahan baku industri berperan strategis bagi Indonesia, baik dari segi ekonomi, sosial dan lingkungan (Boerhendhy \& Amypalupy, 2016). Pengelolaan tanaman karet memiliki banyak keuntungan yang bisa didapat misalnya sebagai penambahan devisa negara, sumber pendapatan masyarakat, menambah peluang pekerjaan, dan bahkan mendorong pertumbuhan ekonomi di suatu wilayah.

Dalam pengolahan karet padat, seperti pembuatan karet remah dan sit asap, salah satu tahapan yang paling penting adalah proses penggumpalan lateks menggunakan bahan penggumpal (koagulan). Proses penggumpalan ini sangat berperan dalam menentukan mutu dari karet yang dihasilkan (Vachlepi et al., 2015). Bahan penggumpal lateks yang selama ini dianjurkan adalah asam formiat. Dengan alasan harga yang relatif mahal dan ketersediaan yang sulit diperoleh, sebagian besar petani karet jarang menggunakan asam formiat dan lebih memilih menggunakan 
penggumpal yang tidak dianjurkan seperti pupuk SP, pupuk TSP, dan tawas (Simanjuntak et al., 2012). Mutu bokar yang rendah disebabkan petani menggunakan bahan pembeku lateks yang tidak dianjurkan. Hal ini akan memacu berkembangnya bakteri perusak antioksidan alami di dalam bokar, sehingga nilai plasticity retention index (PRI) menjadi rendah (Solichin \& Anwar, 2006). Dikarenakan hal tersebut, maka perlu dicari bahan alternatif penggumpal lain yang tidak merusak mutu dan harga relatif murah. Salah satu bahan alternatif penggumpal lateks adalah asap cair dari tempurung kelapa. Penelitian ini bertujuan untuk mencari dosis asap cair dari tempurung kelapa yang terbaik sebagai bahan penggumpal lateks.

\section{METODE PENELITIAN}

Penelitian dilaksanakan pada November 2016 sampai dengan April 2017 di Laboratorium Tanaman Politeknik Negeri Lampung. Pengujian mutu karet Standard Indonesian Rubber (SIR) dilakukan di laboratorium uji mutu SIR PTPN VII, Way Berulu, Gedong Tataan, Kabupaten Pesawaran, Lampung. Alat yang digunakan yaitu gelas ukur, labu erlenmeyer, gelas beaker, kain saring, bak koagulasi, pengaduk, pH meter, stopwatch, gilingan tangan, timbangan, dan alat uji mutu karet. Bahan yang digunakan, lateks, asap cair berbahan tempurung kelapa, asam formiat 5\%, akuades, air, plastik, bahan uji mutu karet (karet crepe).

Metode penelitian menggunakan Rancangan Acak Kelompok (RAK) dengan 6 dosis perlakuan asap cair tempurung kelapa $(\mathrm{T})$ : kontrol (tanpa asap cair tempurung kelapa $+5 \%$ asam formiat), $1 \% \mathrm{v} / \mathrm{v}$ lateks, $1,5 \% \mathrm{v} / \mathrm{v}$ lateks, $2 \% \mathrm{v} / \mathrm{v}$ lateks, $2,5 \% \mathrm{v} / \mathrm{v}$ lateks, dan $3 \% \mathrm{v} / \mathrm{v}$ lateks. Setiap perlakuan diulang sebanyak 4 kali, dan didapatkan 24 satuan percobaan. Analisis data dilakukan melalui analisis sidik ragam dan dilanjutkan dengan uji nilai tengah BNT 5\% menggunakan Minitab ver. 17. Pelaksanaan penelitian dilakukan dalam empat tahap yaitu pembuatan asap cair, penelitian pendahuluan, proses koagulasi lateks dan uji mutu karet SIR. Proses koagulasi lateks menggunakan asap cair dan sebagai kontrol menggunakan asam formiat $5 \%$.

Pengamatan dilakukan terhadap variabel $\mathrm{pH}$ lateks saat menggumpal, lama waktu penggumpalan, rendemen koagulum, dan kadar karet kering (KKK). Variabel mutu yang diamati adalah kadar kotoran, kadar abu, kadar zat menguap, PRI, viskositas mooney, dan indeks warna. Penentuan mutu didasarkan pada SIR SNI 06-1903-2000.

\section{HASIL DAN PEMBAHASAN}

\section{Derajat Keasaman (pH) Asap Cair}

Pada awal penelitian terlebih dahulu $\mathrm{pH}$ asap cair diukur menggunakan alat $\mathrm{pH}$ meter sebelum mencampurkan kedalam lateks sebagai bahan penggumpal. Tercatat $\mathrm{pH}$ asap cair tempurung kelapa adalah 2,69 yang artinya bersifat asam. Menurut Yunus (2011), kandungan senyawa asam yang ada pada asap cair meliputi asamasetat, propionat, butirat, dan valerat. 


\section{Pengaruh Asap Cair pada pH Lateks dan Lama Waktu Gumpal}

Hasil sidik ragam memperlihatkan bahwa perlakuan penambahan asap cair berpengaruh nyata pada $\mathrm{pH}$ dan waktu gumpal lateks. Selanjutnya dilakukan uji nilai tengah BNT dengan taraf kepercayaan 5\% (Tabel 1).

Tabel 1. Uji nilai tengah pengaruh asap cair pada pH dan waktu gumpal lateks

\begin{tabular}{clccc}
\hline No. & \multicolumn{1}{c}{ Perlakuan } & $\mathrm{pH}$ & Waktu gumpal (menit) \\
\hline 1 & Asam formiat 5\% & 5,10 & $\mathrm{~b}$ & $24,75 \quad \mathrm{~d}$ \\
2 & Asap cair 1\% & 5,57 & $\mathrm{~b}$ & $26,00 \mathrm{~d}$ \\
3 & Asap cair 1,5\% & 5,08 & $\mathrm{~b}$ & $20,00 \mathrm{c}$ \\
4 & Asap cair 2\% & 4,97 & $\mathrm{~b}$ & $17,00 \mathrm{~b}$ \\
5 & Asap cair 2,5\% & 4,83 & $\mathrm{a}$ & $14,75 \mathrm{ab}$ \\
6 & Asap cair 3\% & 4,45 & $\mathrm{a}$ & $12,75 \quad \mathrm{a}$ \\
\hline
\end{tabular}

Keterangan: angka pada kolom yang diikuti dengan huruf yang sama menunjukkan tidak berbeda nyata menurut uji BNT 5\%

Pada Tabel 1 dapat dilihat bahwa $\mathrm{pH}$ tertinggi yaitu pada perlakuan penambahan asap cair dosis $1 \%$ yakni 5,57 , sebaliknya untuk $\mathrm{pH}$ terendah terdapat pada perlakuan penambahan asap cair dosis $3 \%$ yakni 4,45 . Semakin besar dosis asap cair yang diberikan maka semakin menurun $\mathrm{pH}$ lateks gumpal yang didapat. Pada penelitian Martrias et al. (2015) penambahan dosis asap cair tempurung kelapa yang lebih banyak juga semakin menunjukkan kemasaman lateks yang rendah.

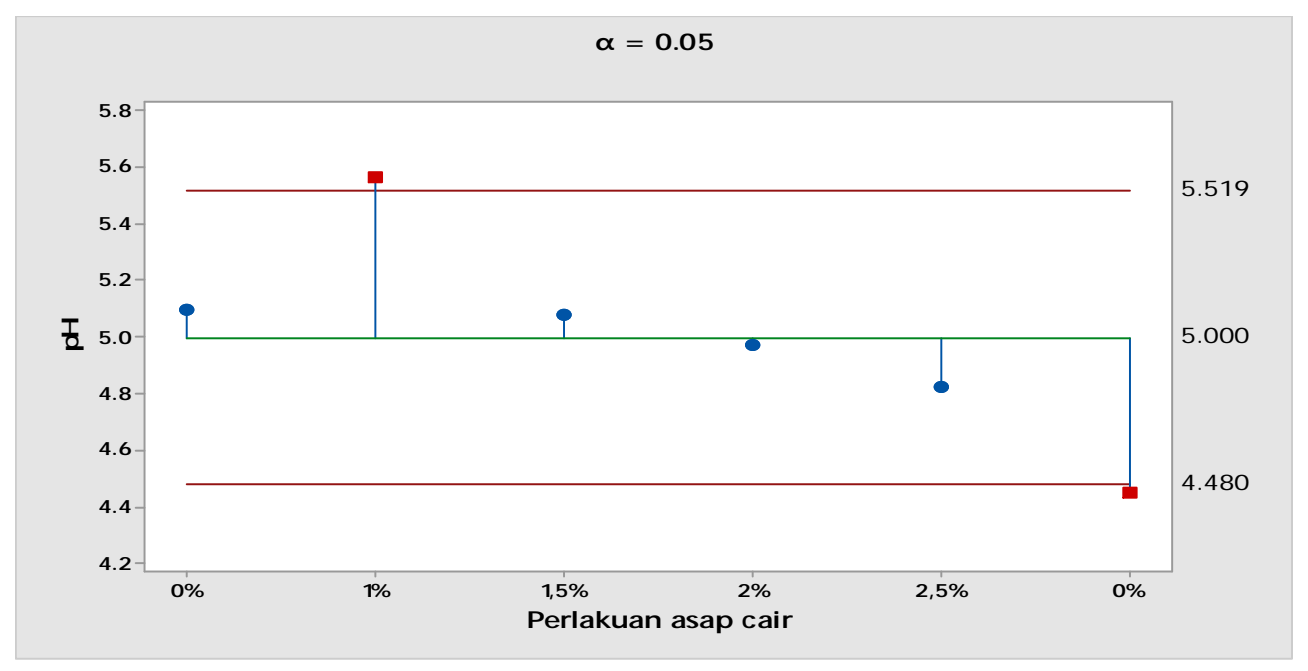

Gambar 1. Uji nilai tengah pengaruh asap cair pada pH lateks 
Berdasarkan Tabel 1 juga nampak bahwa semakin banyak dosis asap cair yang diberikan, semakin cepat proses gumpal terjadi. Menurut Maryanti \& Edison (2016), semakin banyak dosis koagulan yang diberikan akan semakin luas kontak antara lateks dan koagulan, sehingga lapisan selubung protein karet akan cepat terpecah.

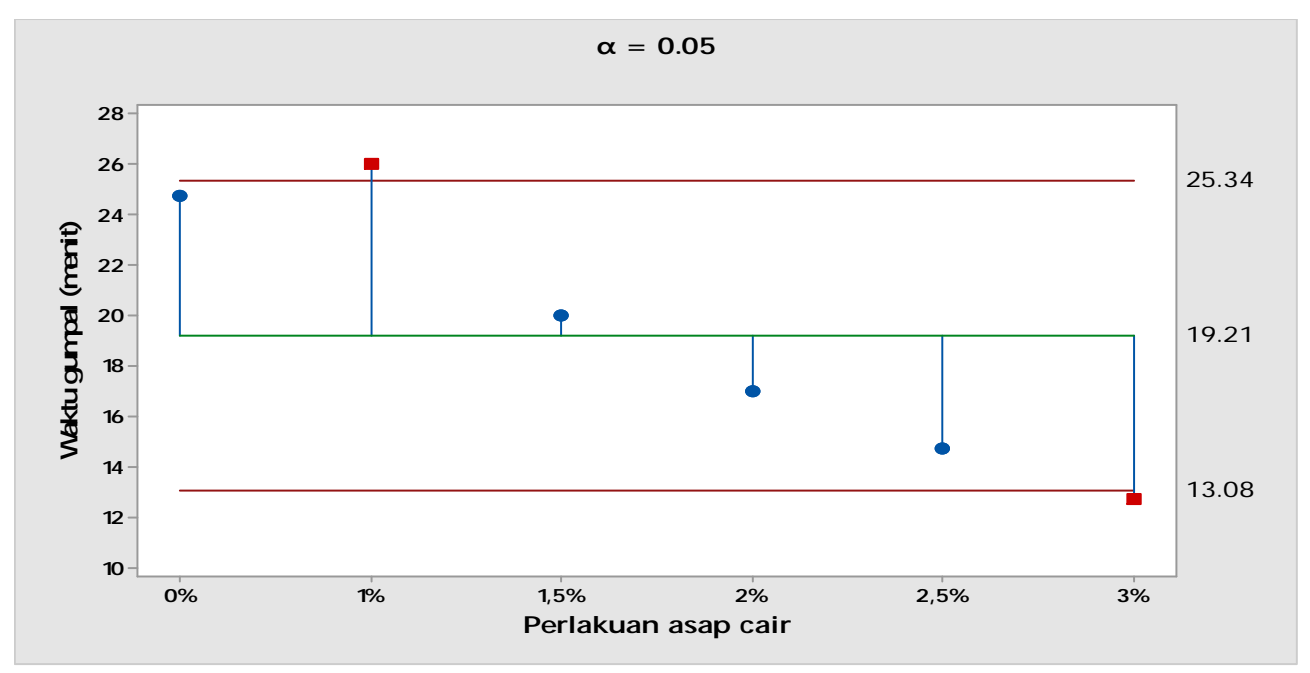

Gambar 2. Uji nilai tengah pengaruh asap cair pada waktu penggumpalan

\section{Pengaruh Asap Cair pada Rendemen Koagulum dan KKK}

Pada Tabel 2 dapat dilihat bahwa penggunaan asap cair pada lateks tidak berpengaruh nyata pada rendemen karet dan juga KKK. Rndemen koagulum tertinggi terapat pada perlakuan dosis 2,5\% dengan rendemen koagulum 38,74 g, namun pada perlakuan dengan dosis yang lebih tinggi yakni 3\% terlihat rendemen koagulum turun menjadi 37,46 g.

Tabel 2. Uji nilai tengah pengaruh asap cair pada rendemen koagulum dan KKK

\begin{tabular}{|c|c|c|c|}
\hline No. & Perlakuan & Rendemen koagulum (g) & KKK (g) \\
\hline 1 & Asam formiat $5 \%$ & 37,50 a & 29,21 a \\
\hline 2 & Asap cair $1 \%$ & 37,26 a & 29,16 a \\
\hline 3 & Asap cair $1,5 \%$ & 38,33 a & 30,08 a \\
\hline 4 & Asap cair $2 \%$ & 38,74 a & 30,12 a \\
\hline 5 & Asap cair $2,5 \%$ & 37,46 a & 29,20 a \\
\hline 6 & Asap cair 3\% & 36,64 a & 29,11 a \\
\hline
\end{tabular}

Keterangan: angka pada kolom yang diikuti dengan huruf yang sama menunjukkan tidak berbeda nyata menurut uji BNT 5\% 


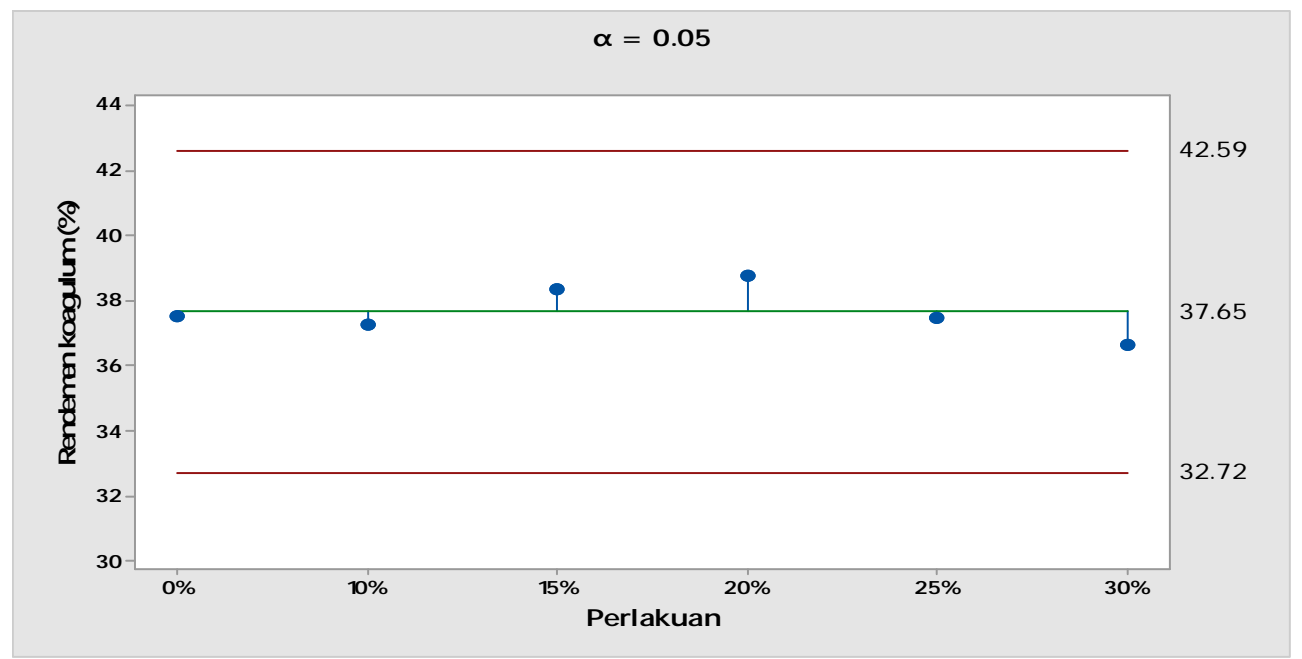

Gambar 3. Uji nilai tengah pengaruh asap cair pada rendemen koagulum

Kandungan KKK tertinggi terdapat pada perlakuan dengan dosis 2,5\% yakni 30,12 g (Tabel 2). Pada penambahan dosis perlakuan menjadi 3\%, KKK menurun jika dibandingkan dengan perlakuan sebelumnya. Hal tersebut menandakan bahwa penggunaan asap cair pada rendemen dan KKK tidak memiliki pengaruh nyata namun dapat dilihat bahwa rendemen koagulum dan KKK berbanding lurus yaitu peningkatan maupun penurunan sama-sama terjadi. Hal tersebut dikarenakan kandungan karet yang ada pada lateks memiliki persen yang sama sehingga kenaikan maupun penurunan sama-sama terjadi. Menurut Vachlepi et al. (2015), kandungan KKK yang ada pada lateks kebun berkisar $30 \%$.

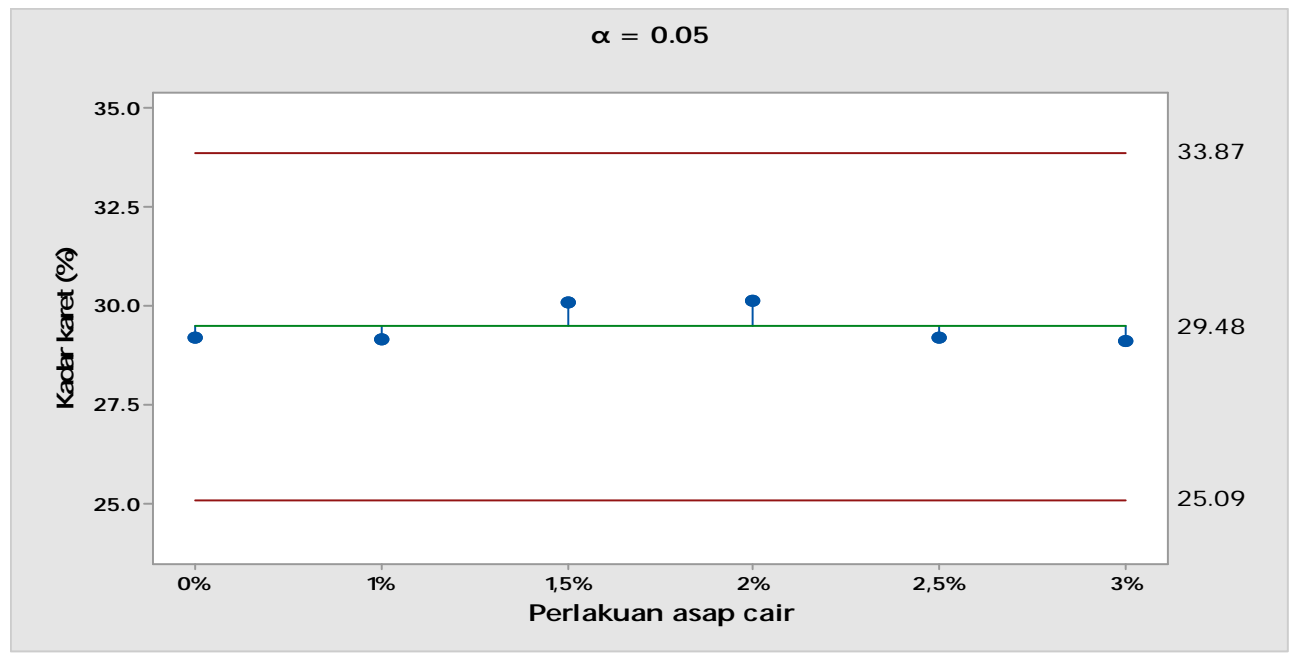

Gambar 4. Uji nilai tengah pengaruh asap cair pada KKK

\section{Pengaruh Asap Cair pada Kadar Kotoran dan Kadar Abu}

Hasil penelitian menunjukkan bahwa perlakuan dosis asap cair tidak berpengaruh pada kadar kotoran dan kadar abu (Tabel 3). Penggunaan asam formiat dan asap cair sebagai 
penggumpal pada penelitian ini menghasilkan karet crepe dengan kandungan kadar kotoran berkisar 0,00925-0,01375\% (Gambar 5). Hal ini menandakan bahwa penggunaan asap cair maupun asam formiat memenuhi SIR SNI 06-1903-2000 yang memperbolehkan kadar kotoran maksimal 0,03-0,2\%, sehingga kadar kotoran pada penelitian ini lebih rendah dari yang telah ditetapkan.

Tabel 3. Uji nilai tengah pengaruh asap cair pada kadar kotoran dan kadar abu

\begin{tabular}{clcc}
\hline No. & Perlakuan & Kadar kotoran $(\%)$ & Kadar abu (\%) \\
\hline 1 & Asam formiat 5\% & $0,01000 \mathrm{a}$ & $0,210 \mathrm{a}$ \\
2 & Asap cair 1\% & $0,00925 \mathrm{a}$ & $0,195 \mathrm{a}$ \\
3 & Asap cair 1,5\% & $0,00975 \mathrm{a}$ & $0,202 \mathrm{a}$ \\
4 & Asap cair 2\% & $0,01275 \mathrm{a}$ & $0,207 \mathrm{a}$ \\
5 & Asap cair 2,5\% & $0,01375 \mathrm{a}$ & $0,215 \mathrm{a}$ \\
6 & Asap cair 3\% & $0,01375 \mathrm{a}$ & $0,210 \mathrm{a}$
\end{tabular}

$\overline{\text { Keterangan: angka pada kolom yang diikuti dengan huruf yang sama menunjukkan tidak berbeda }}$ nyata menurut uji BNT 5\%

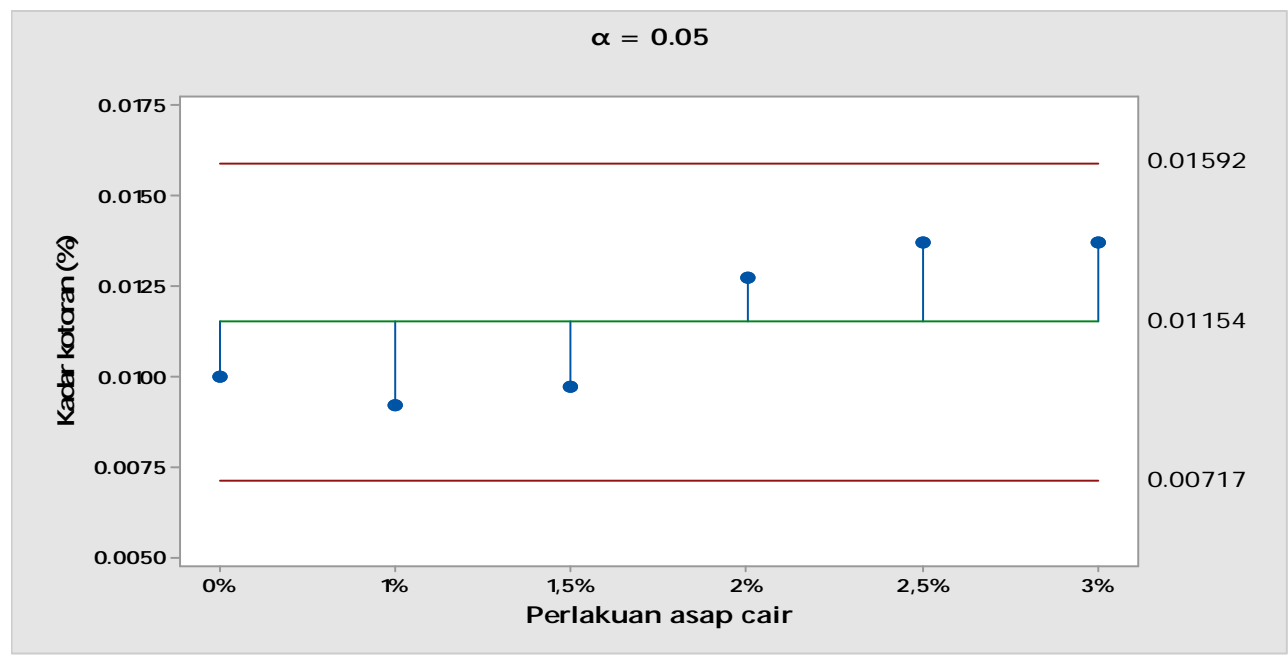

Gambar 5. Uji nilai tengah pengaruh asap cair pada kadar kotoran

Hasil penelitian menunjukkan kadar abu karet crepe berkisar 0,195-0,215\% (Gambar 6). Hal ini menandakan bahwa karet crepe hasil gumpalan asap cair masuk kedalam syarat SIR SNI 06-1903-2000 yang memperbolehkan kadar abu dalam karet crepe maksimal 0,5-1\% dan hasil penelitian ini lebih rendah dari itu. Hal ini sejalan dengan penelitian Sucahyo (2010) yang menggunakan asap cair tempurung kelapa sebagai penggumpal dengan berbagai perlakuan tidak berpengaruh nyata pada kadar abu yakni dengan nilai kadar abu 0,30-0,31\%. 


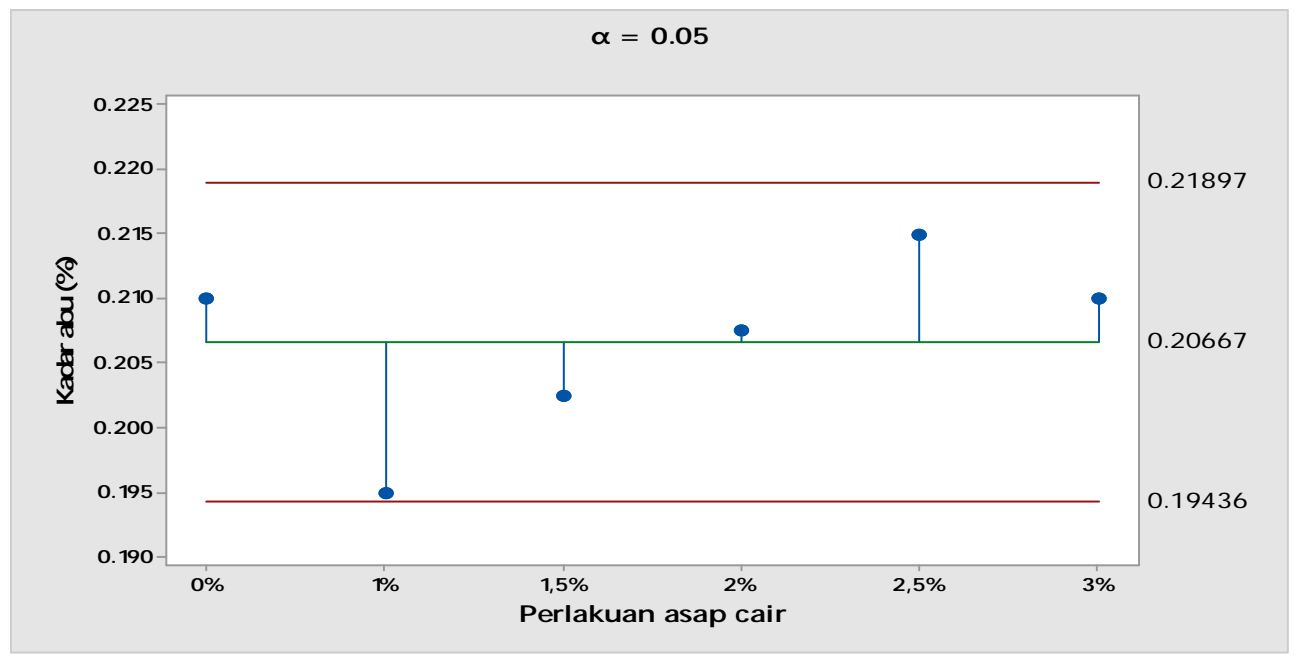

Gambar 6. Uji nilai tengah pengaruh asap cair pada kadar abu

\section{Pengaruh Asap Cair pada Kadar Zat Menguap}

Tabel 4. Uji nilai tengah pengaruh asap cair pada kadar zat menguap

\begin{tabular}{clc}
\hline No. & \multicolumn{1}{c}{ Perlakuan } & Kadar bahan menguap (\%) \\
\hline 1 & Asam formiat 5\% & $0,22 \mathrm{a}$ \\
2 & Asap cair 1\% & $0,22 \mathrm{a}$ \\
3 & Asap cair 1,5\% & $0,22 \mathrm{a}$ \\
4 & Asap cair 2\% & $0,22 \mathrm{a}$ \\
5 & Asap cair 2,5\% & $0,23 \mathrm{a}$ \\
6 & Asap cair 3\% & $0,23 \mathrm{a}$
\end{tabular}

Keterangan: angka pada kolom yang diikuti dengan huruf yang sama menunjukkan tidak berbeda nyata menurut uji BNT 5\%

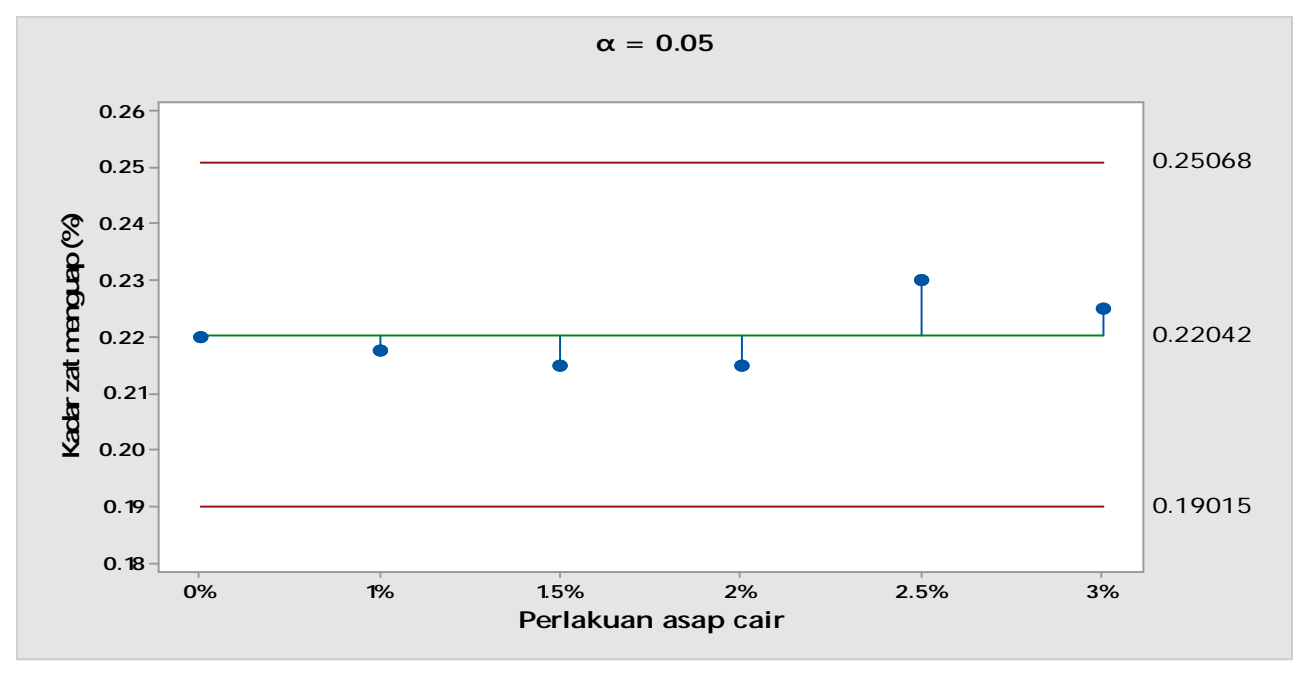

Gambar 7. Uji nilai tengah pengaruh asap cair pada kadar zat menguap 
Tabel 4 memperlihatkan bahwa penggunaan asam formiat dan asap cair memenuhi syarat sebagai penggumpal lateks jika dilihat dari persen bahan menguap karet crepe. Hasil dari penggunaan kedua bahan tersebut sebagai bahan penggumpal, kadar zat menguap lateks hanya berkisar 0,22-0,23\%. Hal tersebut menandakan penggunaan asap cair masuk dalam syarat SIR (Standard Indonesian Rubber) SNI 06-1903-2000 yang memperbolehkan karet crepe dengan kadar maksimal zat menguap $0,8 \%$.

\section{Pengaruh Asap Cair pada PRI}

Penggunaan asap cair tidak memiliki pengaruh yang nyata pada nilai PRI karet crepe Tabel 5). Hasil penelitian menunjukkan penggunaan asam formiat dan asap cair sebagai penggumpal menghasilkan nilai PRI 97,51-98,93. Menurut Solichin \& Anwar (2006), Deorub K dapat mencegah pertumbuhan bakteri (karena adanya fenol) sehingga bakteri tidak berkembang akibatnya adalah tidak terjadi kerusakan antioksidan dalam bentuk protein (asam-asam amino) sehingga nilai Po dan PRI tinggi. Yulita (2012) juga menguatkan bahwa sifat bakteriostatik dari asap cair mampu mengontrol pertumbuhan mikrobia.

Tabel 5. Uji nilai tengah pengaruh asap cair pada PRI

\begin{tabular}{cll}
\hline No. & \multicolumn{1}{c}{ Perlakuan } & PRI (\%) \\
\hline 1 & Asam formiat 5\% & $97,51 \mathrm{a}$ \\
2 & Asap cair 1\% & $97,69 \mathrm{a}$ \\
3 & Asap cair $1,5 \%$ & $97,02 \mathrm{a}$ \\
4 & Asap cair 2\% & $98,20 \mathrm{a}$ \\
5 & Asap cair 2,5\% & $98,05 \mathrm{a}$ \\
6 & Asap cair 3\% & $98,93 \mathrm{a}$
\end{tabular}

Keterangan: angka pada kolom yang diikuti dengan huruf yang sama menunjukkan tidak berbeda nyata menurut uji BNT 5\%

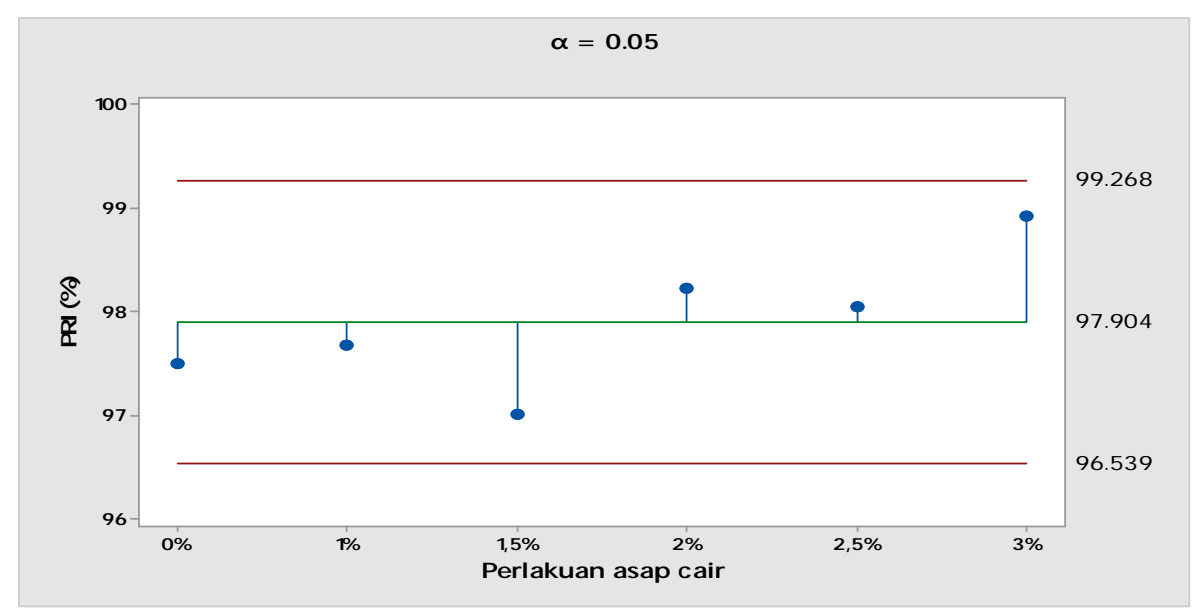

Gambar 8. Uji nilai tengah pengaruh asap cair pada PRI

74 Jurnal AIP Volume 6 No. 2 | Oktober 2018: 67-78 


\section{Pengaruh Asap Cair pada Viskositas Mooney}

Tabel 6. Uji nilai tengah pengaruh asap cair pada viskositas Mooney

\begin{tabular}{llc} 
No. & Perlakuan & Viskositas Mooney $(\%)$ \\
\hline 1 & Asam formiat 5\% & $75,5 \mathrm{a}$ \\
2 & Asap cair $1 \%$ & $76,0 \mathrm{a}$ \\
3 & Asap cair $1,5 \%$ & $79,0 \mathrm{~b}$ \\
4 & Asap cair $2 \%$ & $82,0 \mathrm{c}$ \\
5 & Asap cair 2,5\% & $83,0 \mathrm{~d}$ \\
6 & Asap cair 3\% & $84,5 \mathrm{~d}$
\end{tabular}

Keterangan: angka pada kolom yang diikuti dengan huruf yang sama menunjukkan tidak berbeda nyata

Penggunaan asap cair dan asam formiat pada penelitian ini mendapatkan nilai Viskositas Mooney 75,5-84,5 (Tabel 6 dan Gambar 9). Hal ini menandakan seluruh karet crepe tidak masuk ke dalam syarat SIR SNI 06-1903-2000 yang membataskan parameter viskositas Mooney 50-75. Menurut Vachlepi et al. (2015), parameter viskositas Mooney menggambarkan panjang rantai molekul karet. Semakin tinggi nilai viskositas Mooney semakin panjang rantai molekul karet alam. Karet alam yang memiliki nilai viskositas yang rendah seperti karet LoV (Low Viskositas) lebih mudah dalam proses pencampuran dengan bahan aditif lainnya. Proses pencampuran yang mudah ini dapat mempercepat waktu yang berdampak pada peningkatan efisiensi konsumsi energi.

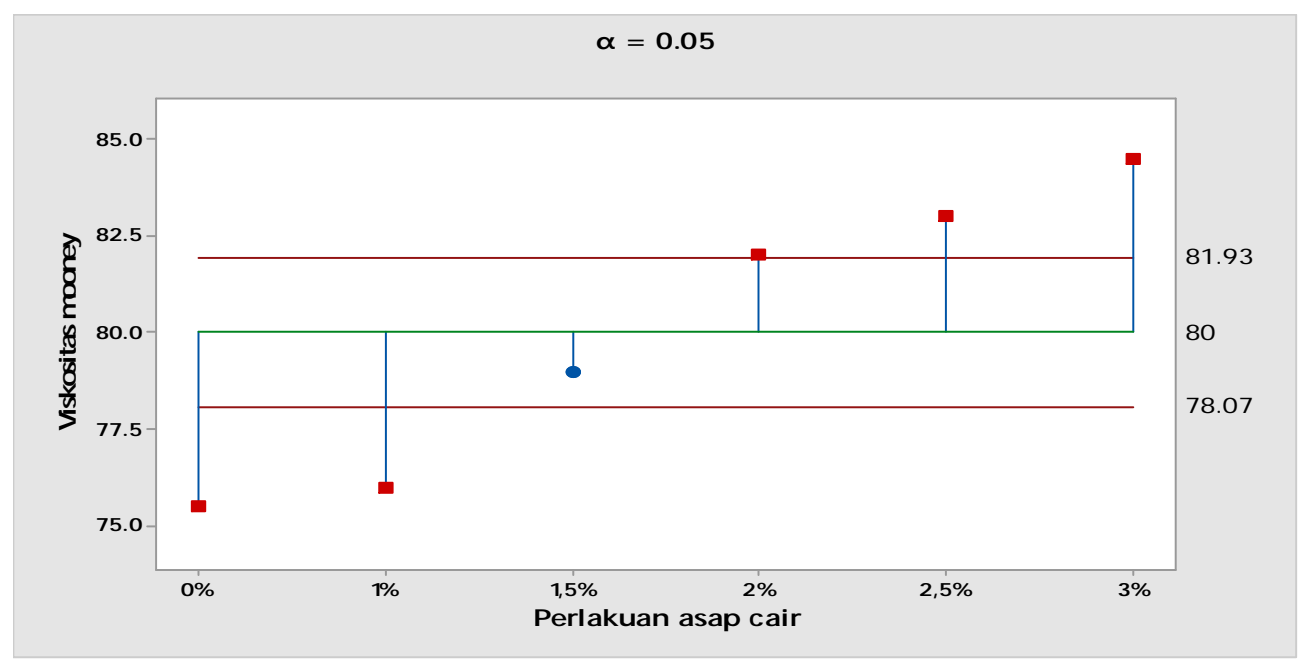

Ganbar 9. Uji nilai tengah pengaruh asap cair pada viskositas Mooney 


\section{Pengaruh Asap Cair pada Indeks Warna}

Seluruh karet crepe tidak masuk ke dalam syarat indeks warna SIR 3L yang ditetetapkan SIR SNI 06-1903-2000 (Tabel 7). Hasil penelitian ini menunjukkan bahwa warna dari karet crepe yang dihasilkan tidak masuk kedalam 6 lovibond yang ditetapkan oleh SIR SNI 06-1903-2000. Menurut Fitriyani et al. (2016), penggumpalan pada pH yang sangat rendah mengakibatkan warna karet crepe semakin gelap. Penutupan yang tidak rapat pada proses penggumpalan menyebabkan terjadinya oksidasi dan menghasilkan warna koagulum abu-abu atau belang. Dapat disimpulkan karet crepe yang didapat tidak masuk kedalam syarat SIR 3L dikarenakan tidak masuk ke dalam 6 lovibond yang telah ditetapkan dan masuk kedalam SIR 3WF.

Tabel 7. Hasil uji indeks warna

\begin{tabular}{cll}
\hline No. & \multicolumn{1}{c}{ Perlakuan } & Indeks warna \\
\hline 1 & Asam formiat 5\% & $>6$ skala lovibond \\
2 & Asap cair 1\% & $>6$ skala lovibond \\
3 & Asap cair 1,5\% & $>6$ skala lovibond \\
4 & Asap cair 2\% & $>6$ skala lovibond \\
5 & Asap cair 2,5\% & $>6$ skala lovibond \\
6 & Asap cair 3\% & $>6$ skala lovibond \\
\hline
\end{tabular}

\section{Penentuan Mutu Karet Crepe}

Tabel 8. Penentuan mutu karet crepe

\begin{tabular}{|c|c|c|c|c|c|c|c|}
\hline Perlakuan & $\begin{array}{c}\text { Kadar } \\
\text { kotoran } \\
(\%)\end{array}$ & $\begin{array}{c}\text { Kadar } \\
\text { abu } \\
(\%)\end{array}$ & $\begin{array}{c}\text { Kadar Zat } \\
\text { menguap } \\
(\%)\end{array}$ & PRI (\%) & $\begin{array}{c}\text { Viskositas } \\
\text { Mooney }\end{array}$ & $\begin{array}{l}\text { Indeks } \\
\text { warna }\end{array}$ & $\begin{array}{l}\text { Hasil } \\
\text { mutu }\end{array}$ \\
\hline Asam formiat $5 \%$ & 0,010 & 0,2100 & 0,2200 & 97,5100 & 75,5 & $\begin{array}{l}>6 \text { skala } \\
\text { lovibond }\end{array}$ & SIR $3 \mathrm{WF}$ \\
\hline Asap cair $1 \%$ & 0,009 & 0,1950 & 0,2175 & 97,6850 & 76,0 & $\begin{array}{l}>6 \text { skala } \\
\text { lovibond }\end{array}$ & SIR 3WF \\
\hline Asap cair $1,5 \%$ & 0,010 & 0,2025 & 0,2150 & 97,0175 & 79,0 & $\begin{array}{l}>6 \text { skala } \\
\text { lovibond }\end{array}$ & SIR 3WF \\
\hline Asap cair $2 \%$ & 0,013 & 0,2075 & 0,2150 & 98,2325 & 82,0 & $\begin{array}{l}>6 \text { skala } \\
\text { lovibond }\end{array}$ & SIR 3WF \\
\hline Asap cair $2,5 \%$ & 0,014 & 0,2150 & 0,2300 & 98,0500 & 83,0 & $\begin{array}{l}>6 \text { skala } \\
\text { lovibond }\end{array}$ & SIR 3WF \\
\hline Asap cair 3\% & 0,014 & 0,2100 & 0,2250 & 98,9275 & 84,5 & $\begin{array}{l}>6 \text { skala } \\
\text { lovibond }\end{array}$ & SIR 3WF \\
\hline
\end{tabular}


Tabel 8 memperlihatkan bahwa seluruh hasil perlakuan menggunakan asap cair dan asam formiat menghasilkan karet crepe dengan mutu SIR 3WF. Faktor utama tidak masuknya karet crepe ke SIR 3L adalah warna yang melebihi batas 6 lovibond ketetapan SIR SNI 06-1903-2000.

\section{KESIMPULAN DAN SARAN}

\section{Kesimpulan}

Dosis asap cair yang efektif digunakan sebagai koagulan lateks yaitu dosis $1 \%$ yang membutuhkan waktu penggumpalan selama 26 menit, waktu tersebut tidak berbeda jauh dengan kontrol (asam formiat) yakni 24,75 menit. Dosis asap cair tempurung kelapa $1 \%$ yang digunakan sebagai koagulan lateks pada penelitan ini menghasilkan mutu karet crepe SIR 3WF dengan kadar kotoran, kadar abu, kadar zat menguap, PRI, dan viskositas Mooney secara berturut-turut yaitu $0,009 \%, 0,1950 \%, 0,2175 \%, 97,6850 \%$, dan 76,0 .

\section{Saran}

Pada penelitian ini mutu karet yang dihasilkan yaitu SIR 3WF dan tidak masuk kedalam syarat SIR 3L dikarenakan warna karet crepe yang dihasilkan melebihi 6 skala lovibond. Diperlukan penelitian lebih lanjut menggunakan asap cair tempurung kelapa sebagai koagulan namun menghasilkan karet crepe yang masuk ke dalam SIR 3L.

\section{DAFTAR PUSTAKA}

Boerhendhy, I., \& Amypalupy, K. (2016). Optimalisasi produktivitas karet melalui penggunaan bahan tanam, pemeliharaan, sistem eksploitasi dan peremajaan tanaman. Jurnal Penelitian dan Pengembangan Pertanian, 30(1), 23-30.

Fitriyani, L., Fitriani, F., \& Edison, R. (2016). Analisis Pengendalian Kualitas Produk SIR 3L di PT Perkebunan Nusantara VII Unit Usaha Way Berulu. Jurnal Agro Industri Perkebunan, 4(2), 106-117.

Martrias, D., Edison, R., \& Supriyatdi, D. (2015). Penggunaan Asap Cair dan Arang Aktif Tempurung Kelapa pada Mutu Karet Krep. Jurnal Agro Industri Perkebunan, 3(1), 1-10.

Maryanti, M., \& Edison, R. (2016). Pengaruh Dosis Serum Lateks terhadap Koagulasi Lateks (Hevea brasiliensis). Jurnal Agro Industri Perkebunan, 4(1), 54-59..

Simanjuntak, M., Bachtiar, B., \& Rachmawan, A. (2012). Pengujian Mutu Kritex SP Sebagai Penggumpal Lateks. Jurnal Penelitian Karet, 30(2), 108-116.

Solichin, M., \& Anwar, A. (2006). Deorub K Pembeku Lateks dan Pencegah Timbulnya Bau Busuk Karet. Tabloid Sinar Tani. Jakarta.

Sucahyo, L. (2010). Kajian Pemanfaatan Asap Cair Tempurung Kelapa sebagai Bahan Koagulan Lateks dalam Pengolahan Ribbed Smoked Sheet (RSS) dan Pengurang Bau Busuk Bahan Olahan Karet. Upbulished undergraduate thesis, Institut Pertanian Bogor, Bogor. 
Vachlepi, A., Suwardin, D., \& Purbaya, M. (2015). Karakterisasi Kondisi Penggumpalan Dan Mutu Karet Yang Digumpalkan Dengan Koagulan Deorub Formula Baru. Jurnal Penelitian Karet, 33(2), 175-182.

Yulita, E. (2012). Pengaruh asap cair serbuk kayu limbah industri terhadap mutu bokar. Journal of Industrial Research (Jurnal Riset Industri), 6(1), 13-22.

Yunus, M. (2011). Teknologi pembuatan asap cair dari tempurung kepala sebagai pengawet makanan. Jurnal Sains dan Inovasi, 7(1), 53-61. 